\title{
PENGARUH HARGA, LOKASI DAN KUALITAS PRODUK TERHADAP KEPUTUSAN PEMBELIAN KONSUMEN CV. ZAFIRA TEKNIK PEKANBARU
}

\author{
Putra Budi Ansori \\ Sekolah Tinggi Ilmu Ekonomi Riau \\ E-mail: pbansori@gmail.com
}

\begin{abstract}
This research was conducted in the research conducted at CV.Zafira Teknik Pekanbaru, SM.Amin, Pekanbaru City in 2019. This study was to determine the effect of price, location and product quality on consumer purchasing decisions CV. Zafira Teknik Pekanbaru. The population in this study are consumers who buy doors and repair doors at CV. Zafira Teknik Pekanbaru 2018 is 1,188 people. With a sample of 92 people with a sampling method based on purposive sampling. From the analysis of multiple linear regression equation was formulated: $Y=2,620+0,371 X 1+0,143 X 2+0,336 X 3$. The results of the $t$ test (partial test) obtained the value of $t$ arithmetic for Pricel X1 $(5,077)$ and product quality/ X3 (3,208) greater than t table of 1,98729, then it has a significant effect on consumer purchasing decisions CV. Zafira Teknik Pekanbaru. Whereas the Location /X2 variable does not significantly influence the consumer purchasing decision variable CV. Zafira Teknik Pekanbaru, this is because the value of $t$ _count (1.340) <t_tabel (1.98729). F Test Results (joint test), it is concluded that $F$ count is 28.304> F table 2.71 so that simultaneously the variables of Price, location, and product quality on consumer purchasing decisions CV. Zafira Teknik Pekanbaru. . There are contribution the influence of variables of Price, location, and product quality on consumer purchasing decisions $C V$. Zafira Teknik Pekanbaru of Obtained value of Adjusted $R$ Square equal to 0,471 or 47,1\% and 52,9\% influenced by the other factors that are not pursuing in this research. So this research to strengthen previous studies
\end{abstract}

Keywords: Price, location, product quality and purchase decision

\section{A. PENDAHULUAN}

Kemajuan kota Pekanbaru disebabkan pertambahan penduduk, berkembangnya kegiatan ekonomi dan semakin terhubungnya akses antar kota-ke kota dalam provinsi atau antar provinsi. Hingga pembangunan perumahan dan pertokoan menjadi salah satu indikator perkembangan tersebut. Perusahan CV. Zafira Teknik ini menjadikan perkembangan ini sebagai peluang dalam usaha pembuatan produk pintu folding gate.

Hingga persaingan harga, kualitas produk dan ketepatan dalam menentukan lokasi usaha menjadi pertimbangan pemilik usaha dalam memenangkan persaingan dalam usaha ini. CV. Zafira Teknik hadir dengan menawarkan alternatif harga yang terjangkau dan kualitas yang baik hingga menjadi pertimbangan keputusan pembelian konsumen dalam memenuhi kebutuhan mereka akan produk pintu folding gate. Berarti adanya persaingan, perusahaan dituntut untuk dapat mengambil langkahlangkah yang tepat agar dapat menguasai pasar.

Tindakan-tindakan yang dilakukan oleh individu, kelompok maupun organisasi yang berhubungan dengan proses pengambilan keputusan dalam memilih, membeli dan memakai barang atau jasa, semata-mata untuk memuaskan kebutuhannya. Menurut Kotler (2012: 223) "keputusan pembelian adalah beberapa tahapan yang dilakukan oleh konsumen sebelum melakukan keputusan pembelian suatu produk". Terjadinya keputusan pembelian karena konsumen membutuhkan, tertarik, dan manfaat produk itu sendiri.

Agar dapat sukses dalam memasarkan suatu barang atau jasa, setiap perusahaan atau organisasi harus menetapkan harga secara tepat. Dimana tinggi rendahnya harga yang diberikan kepada konsumen berpengaruh terhadap laku atau tidaknya suatu produk di pasaran. Menurut Tjiptono (2014:151) "harga adalah satuan moneter atau ukuran lainnya, (termasuk barang dan jasa lainnya) yang ditukarkan agar memperoleh hak kepemilikan penggunaan suatu barang atau jasa"

Begitu juga dengan lokasi sangat penting dalam keputusan pembelian, karena lokasi yang strategis membuat konsumen lebih mudah dijangkau transportasi dan minimnya lahan parkir mempengaruhi 
konsumen untuk membeli produk yang diinginkan. Kualitas merupakan salah satu bagian penting dan sangat perlu mendapatkan perhatian yang seriu Dibawah ini adalah tabel jenis produksi pintu folding gate yang ditawarkan oleh CV. Zafira Teknik sesuai dengan kemapuan keuangan konsumen dengan kualitas terjamin

Tabel. 1

Jenis pintu Folding Gate

pada CV. Zafira Teknik Pekanbaru

\begin{tabular}{|c|c|c|}
\hline No & Produk & Harga per unit \\
\hline 1 & Ketebalan daun 05 & Rp. 3.150000 \\
\hline 2 & Ketebalan daun 08 & Rp. 3.850 .000 \\
\hline
\end{tabular}

Sumber : CV. Zafira Teknik Pekanbaru 2020.

Berikutnya tabel perbandingan produk CV. Zafira Teknik dengan kualitas produk dari merk lain sebagai kompetitor, yaitu:, yaitu:

\begin{tabular}{|c|c|c|c|c|}
\hline No & Kualitas Produk & Zafira & Royal & SPU \\
\hline 1 & Ketebalan Daun & $0,8 \mathrm{~mm}$ & $0,55 \mathrm{~mm}$ & $0,7 \mathrm{~mm}$ \\
\hline 2 & Motif & Polos & Ukir & Bunga \\
\hline 3 & Bahan Handel & Stenlis & Plastik & Plastik \\
\hline 4 & Plat Strip & $\begin{array}{l}\text { Tebal } \\
6 \mathrm{~mm}\end{array}$ & $\begin{array}{l}\text { Tebal } \\
4 \mathrm{~mm}\end{array}$ & $\begin{array}{l}\text { Tebal } \\
5 \mathrm{~mm}\end{array}$ \\
\hline 5 & Profil & Ukir & Polos & Ukir \\
\hline
\end{tabular}

Tabel tersebut dapat diartikan produk CV. Zafira Teknik lebih unggul di bandingkan produk perusahaan lainnya. SPU berada diurutan kedua untuk kategori produk yang lebih baik, sedangkan Royal berada kualitas terendah dibandingkan perusahaan lainnya.

CV. Zafira Teknik ini dengan beralamat jalan SM. Amin, Kelurahan Simpang Baru, Kecamatan Tampan selama tahun 2018 konsumen yang membeli pintu yaitu 1.188 orang.

Berdasarkan latar belakang yang telah diuraikan diatas bahwa keputusan pembelian dapat mempengaruhi faktor lokasi, kualitas produk dan harga dapat menjadi pertimbangan dalam keputusan pembelian konsumen dalam membeli produk CV. Zafira Teknik. Selanjutnya penulis tertarik mengadakan penelitian terhadap konsumen dengan judul: Pengaruh Harga, Lokasi dan Kualitas Produk berpengaruh terhadap

Eko dan Bisnis (Riau Economics and Business Reviewe) Volume 11, Nomor 1, 27 Maret 2020 keputusan pembelian konsumen CV.Zafira Teknik Pekanbaru.

\section{TINJAUAN PUSTAKA \\ Manajemen Pemasaran}

Para ahli banyak mendefinisikan pengertian dari pemasaran. Diantaranya menurut American Marketing Association dalam Assauri (2009: 3) pemasaran merupakan hasil prestasi kegiatan usaha yang berkaitan dengan mengalirnya barang dan jasa dari produsen sampai konsumen.

Selanjutnya, Assauri (2009:5) pemasaran sebagai kegiatan manusia yang diarahkan untuk memenuhi dan memuaskan kebutuhan serta keinginan melalui proses pertukaran.

Menurut Basu Swasta (2008:5), Pemasaran adalah suatu sistem keseluruhan dari kegiatan-kegiatan bisnis yang ditujukan untuk merencanakan, menentukan harga, mempromosikan dan mendistribusikan barang dan jasa yang memuaskan kebutuhan baik kepada pembeli yang ada maupun pembeli potensial.

\section{Keputusan Pembelian}

Harga, Lokasi dan Kualitas Produk merupakan faktor penting yang ikut berpengaruh pada keputusan pembelian. Pada kajian pemasaran terdapat istilah yang dikenal dengan marketing mix atau bauran pemasaran yang terdiri dari produk, harga, lokasi (saluran distribusi), dan promosi.

Menurut Schiffman dan Kanuk dalam buku Sangadji dan Sopiah (2013: 120) mendefinisikan keputusan sebagai pemilihan suatu tindakan dari dua pilihan alternatif atau lebih. Seorang konsumen yang hendak memilih harus memiliki pilihan alternative.

Selanjunya Sangadji dan Sopiah (2013:121) “....inti dari pengambilan keputusan konsumen adalah proses pengintegrasian yang mengkombinasikan pengetahuan untuk mengevaluasi dua perilaku alternatif atau lebih, dan memilih

$$
\text { P.ISSN: 1410-7988 E.ISSN: 2614-123X }
$$


salah satu diantaranya. Hasil dari proses pengintegrasian ini adalah suatu pilihan yang disajikan secara kognitif sebagai keinginan berprilaku. Dari penjelasan tersebut diatas dapat ditarik kesimpulan bahwa semua perilaku sengaja dilandaskan pada keinginan yang dihasilkan ketika konsumen secara sadar memilih salah satu di antara alternatif yang ada.

Kelima tahapan perilaku konsumen dalam pengambilan keputusan pembelian, berdasarkan pendapat Engel dalam buku Sangadji dan Sopiah (2013: 334) diatas, kemudian penulis jadikan indikator, yaitu:

1. Pengenalan kebutuhan.

2. Pencarian informasi.

3. Evaluasi alternatif.

4. Keputusan pembelian.

5. Hasil setelah pembelian.

\section{Harga}

Menurut Tjiptono (2014:151) "harga adalah satuan moneter atau ukuran lainnya, (termasuk barang dan jasa lainnya) yang ditukarkan agar memperoleh hak kepemilikan penggunaan suatu barang atau jasa". Kotler dan Amstrong (2009:5) "harga yang diajukan oleh perusahaan akan gagal bila berada terlalu tinggi dapat menghasilkan permintaan dan bila terlalu rendah akan menghasilkan keuntungan".

Menurut Kotler (2009: 345),

indikator harga meliputi:

a. Keterjangkauan harga

b.Kesesuaian harga dengan kualitas produk

c. Daya saing harga

\section{Lokasi}

Tempat (place) atau biasa disebut lokasi merupakan kedudukan perusahaan dalam melakukan kegiatan agar produk yang dihasilkan atau dijual terjangkau serta tersedia bagi pasar sasaran. Lokasi merupakan gabungan antara lokasi. dan keputusan atas saluran distribusi dalam hal ini berhubungan dengan bagaimana cara menyampaikan kepada para konsumen dimana lokasi yang strategis.

Eko dan Bisnis (Riau Economics and Business Reviewe) Volume 11, Nomor 1, 27 Maret 2020
Menurut Lempoy, dkk (2015:1081), Lokasi adalah tempat perusahaan beroperasi atau tempat perusahaan melakukan kegiatan untuk menghasilkan barang dan jasa yang mementingkan segi ekonominya. Lokasi yang strategis dan mudah dijangkau akan memudahkan kosumen untuk mengingat suatu objek atau tempat. Semakin baiknya Lokasi akan meningkatkan keputusan menggunakan konsumen. Dan sebaliknya dengan penurunan kualitas lokasi maka keputusan menggunakan akan menurun. Hasil penelitian menunjukkan bahwa lokasi berpengaruh signifikan terhadap keputusan menggunakan konsumen di Taman Wisata Toar Lumimuut Sonder. Dengan lokasi yang semakin baik dan strategis maka akan mengundang ketertarikan konsumen untuk berwisata dan melakukan keputusan menggunakan. Lokasi Taman Wisata Toar Lumimuut Sonder yang berada di Minahasa Induk, Sulawesi Utara yang menjadi sentra pariwisata. Konsumen dari berbagai pelosok mampu mencapai Taman WisataToar Lumimuut Sonder, sehingga konsumen yang menggunakan meningkat drastis dibandingkan dengan lokasi yang kurang strategis.

Hasil penelitian ini dibuktikan dengan penelitian Ghanimata (2012) yang menemukan bahwa lokasi mempunyai pengaruh positif terhadap keputusan pembelian.

Adapun faktor-faktor yang harus dipertimbangkan dalam menentukan pertimbangan pertimbangan yang cermat dalam menentukan lokasi menurut Kotler dan Amstrong (2009:84) meliputi faktor:

1. Akses, misalnya lokasi yang mudah dilalui atau mudah dijangkau sarana transportasi umum.

2. Visibilitas, misalnya lokasi dapat dilihat dengan jelas dari tepi jalan.

3. Tempat parkir yang luas dan aman.

4. Ekspansi, yaitu tersedia tempat yang cukup luas untuk peluasan usaha di kemudian hari.

5. Lingkungan, yaitu daerah sekitar yang mendukung jasa yang ditawarkan.

P.ISSN: 1410-7988 E.ISSN: 2614-123X 


\section{Kualitas Produk}

Kualitas merupakan salah satu bagian penting dan sangat perlu mendapatkan perhatian yang serius bagi perusahaan untuk tetap bertahan dan menjadi pilihan konsumen.

Kotler and Armstrong (2004) dalam Putro Shandy Widjoyo, Hatane Semuel, Ritzky Karina (2014) menyatakan kualitas produk sebagai "the ablity of a product to perform its functions. Its includes the product's overall durability, reliability, precision, ease of operation and repair, and other valued attributes". Artinya kualitas produk berhubungan erat dengan kemampuan produk untuk menjalankan fungsinya, termasuk keseluruhan produk, keandalan, ketepatan, kemudahan pengoperasian dan perbaikan, dan atribut bernilai lainnya.

Jadi kualitas produk merupakan sekumpulan ciri dan karakteristik dari barang dan jasa yang mempunyai kemampuan untuk memenuhi kebutuhan, yang merupakan suatu pengertian gabungan dari keandalan, ketapatan, kemudahan, pemeliharaan serta atribut-atribut lainnya dari suatu produk. Produk yang ditawarkan setiap badan usaha akan berbeda dan pasti mempunyai karakteristik yang membedakan produk itu dengan produk pesaing walaupun jenis produknya sama sehingga produk itu memiliki keunikan, keistimewaan, keunggulan dalam meraih pasar yang ditargetkan.

Menurut Tjiptono (2010:25) menyatakan bahwa kualitas produk dapat diukur dengan menggunakan beberapa indikator diantaranya sebagai berikut :

1. Kinerja(Performance).Merupakan elemen kualitas produk yang berkaitan langsung dengan bagaimana suatu produk dapat menjalankan fungsinya untuk memenuhi kebutuhan konsumen.

2. Keandalan(Reliability).Merupakan daya tahan produk selama dikomunikasi.

3. Keistimewaan tambahan (Features). Merupakan fungsi - fungsi sekunder yang ditambahkan pada suatu produk, misal fitur kendali jauh.

Eko dan Bisnis (Riau Economics and Business Reviewe) Volume 11, Nomor 1, 27 Maret 2020
4. Keawetan (Durability). Dimensi kualitas produk yang menunjukkan suatu pengukuran terhadap siklus produk, baik secara teknis maupun waktu. Produk dikatakan awet jika dapat bertahan dalam pemakaian yang berulang - ulang.

5. Kesesuaian dengan spesifikasi (Conformance to Specifications) yaitu sejauh mana karakteristik desain dan operasi memenuhi standar-standar yang telah ditetapkan sebelumnya. Misalnya standar keamanan dan emisi terpenuhi, seperti ukuran as roda untuk truk tentunya harus lebih besar daripada mobil sedan.

6. Estetika (Asthethic) yaitu daya tarik produk terhadap panca indera.Misalnya bentuk fisik produk yang menarik, model atau desain yang artistik, warna, dan sebagainya.

\section{Hipotesis}

Berdasarkan perumusan masalah dan tinjauan pustaka, serta hubungan antar variabel yang dikemukakan diatas maka didapat dibuat beberapa hipotesis. Menurut Sugiyono (2013:134) hipotesis merupakan jawaban sementara terhadap rumusan masalah penelitian, dimana rumusan masalah penelitian telah dinyatakan dalam bentuk kalimat pernyataan. Dikatakan sementara karena jawaban yang diberikan baru didasarkan pada teori yang relevan, belum berdasarkan pada fakta-fakta empiris yang diperoleh melalui pengumpulan data. Berikut ini beberapa hipotesis dalam penelitian ini, yaitu:

H1 : Harga, Lokasi dan Kualitas Produk berpengaruh signifikan secara simultan terhadap keputusan pembelian konsumen CV.Zafira Teknik Pekanbaru.

H2 :Harga berpengaruh signifikan secara parsial terhadap keputusan pembelian konsumen CV.Zafira Teknik Pekanbaru

H3 :Lokasi berpengaruh signifikan secara parsial terhadap keputusan pembelian konsumen CV.Zafira Teknik Pekanbaru

P.ISSN: 1410-7988 E.ISSN: 2614-123X 


\section{H3 :Kualitas Produk berpengaruh signifikan secara parsial terhadap keputusan pembelian konsumen CV.Zafira Teknik Pekanbaru}

\section{METODE}

Penelitian ini dilakukan pada CV. Zafira Teknik dengan beralamat jalan SM. Amin, Kelurahan Simpang Baru, Kecamatan Tampan Pekanbaru.

Teknik analisa data menggunakan analisis kuantitatif. Dengan metode regresi linear berganda, yaitu suatu metode statistik yang digunakan untuk mengetahui pengaruh antara beberapa variabel bebas terhadap variabel terikat.

Populasi dalam penelitian ini adalah konsumen yang membeli pintu dan melakukan perbaikan pintu pada CV. Zafira Teknik Pekanbaru 2018 yaitu 1.188 orang. Dengan sampel sebanyak 92 orang dengan metode pengambilan sampel berdasarkan purposive sampling. Menurut Sugiyono (2013) Sampling Purposive adalah yaitu teknik penentuan sampel dengan pertimbangan tertentu. Pertimbangannya adalah sampel yang menjadi konsumen atau pernah membuat atau perbaikan folding gate.

Metode pengumpulan data yang digunakan dalam penelitian ini meliputi metode kuesioner, wawancara dan observasi (Umar, 2005:46). .Sesuai dengan jenis dan sifat penelitian ini, maka seluruh data yang akan dikumpulkan disusun sistematis dan deskriptif. Metode analisis data yang digunakan dalam penelitian ini adalah skala likert digunakan untuk mengukur sikap, pendapat, dan presepsi sosial, Skor jawaban respondent dalam penelitian.

Untuk membantu dalam pengolahan data tersebut digunakan program SPSS (Statistical Package For Social Science). Sedangkan alat uji yang digunakan untuk menguji persamaan regresi serta koefisien determinasi dan standar errornya dan untuk melihat pengaruh dari variabel bebas (independen) terhadap variabel terikat (dependen) di dalam penulisan ini.

\section{HASIL}

CV. Zafira Teknik merupakan usaha Pembuatan pintu folding gate yang didirikan oleh Amril pada tanggal 12 Agustus 2009. Selama 11 tahun menjalani usaha pembuatan pintu folding gate ini banyak hal yang sudah dialami oleh perusahaan ini bahkan pernah membuat cabang di jalan Melati dan menangani pengerjaan pintu langsung di lokasi proyek. Saat ini semua kegiatan perusahaan di satukan di jalan SM Amin saja dengan pertimbangan biaya operasional dan ketatnya persaingan pada usaha ini di Pekanbaru. Instrumen penelitian berupa kuesioner terdiri variabel Harga (X1) 5 pernyataan, variabel Lokasi (X2) 5 pernyataan, variabel Kualitas Produk (X3) 5 pernyataanan maka jumlah pernyataan sebanyak 15 item. Kemudian Keputusan Konsumen sebanyak 5 pernyataan.

\section{Uji Validitas}

Uji validitas digunakan untuk mengukur sah atau valid tidaknya suatu kuisioner, uji validitas dilakukan dengan membandingkan nilai $r$ hitung dengan $r$ tabel pada taraf signifikan $5 \%$ untuk uji 2 sisi, jika $r$ hitung $\geq \mathrm{r}$ tabel maka alat ukur yang digunakan dinyatakan valid dan sebaliknya, jika $r$ hitung $\leq r$ tabel maka alat ukur yang digunakan tidak valid (Agus Purwoto, 2008).

Uji validitas akan menguji masingmasing variabel yang digunakan dalam penelitian ini, dimana keseluruhan variabel diperoleh nilai $r$ hitung seluruh pernyataan $>\mathrm{r}$ tabel $(0,2050)$.

Berdasarkan hasil perhitungan uji validitas variabel Harga (X1) 5 pernyataan, variabel Lokasi (X2) 5 pernyataan, variabel Kualitas Produk (X3) 5 pernyataanan maka jumlah pernyataan sebanyak 15 item. Kemudian Keputusan Pembelian sebanyak 5 pernyataan. alat ukur tersebut semua dinyatakan valid. Artinya adalah alat ukur yang digunakan valid dan bisa digunakan sebagai alat pengumpul data. 


\section{Uji Realibilitas}

Koefisien cronbach alpha yang lebih dari 0,60 menunjukkan keandalan (reliabilitas) instrumen. Selain itu, yang semakin mendekati 1 menunjukkan semakin tinggi konsistensi internal reliabilitasnya.

\section{Tabel 3}

Hasil Uji reliabilitas

\begin{tabular}{|l|l|l|l|}
\hline Variabel & $\begin{array}{l}\text { Cronbach's } \\
\text { Alpha }\end{array}$ & $\begin{array}{l}\text { Batas } \\
\text { Reliabilitas }\end{array}$ & Keterangan \\
\hline Harga(X1) & 0,837 & 0.60 & Reliabel \\
\hline Lokasi (X2) & 0,681 & 0.60 & Reliabel \\
\hline Kualitas Produk (X3) & 0,664 & 0.60 & Reliabel \\
\hline $\begin{array}{l}\text { Keputusan Pembelian } \\
\text { Y) }\end{array}$ & 0,784 & 0.60 & Reliabel \\
\hline
\end{tabular}

Sumber : Data Olahan, 2020.

Berdasarkan tabel diatas bahwa nilai koefisien Alpha dari variabel-variabel yang diteliti menunjukkan hasil yang beragam dan variabel menghasilkan nilai Cronbach Alpha lebih besar dari 0,60. Dengan demikian dapat disimpulkan bahwa alat ukur yang digunakan dalam penelitian ini adalah dapat diandalkan (realiabel).

\section{Koefisien Determinasi $\left(\mathbf{R}^{\mathbf{2}}\right)$}

Besarnya sumbangan pengaruh variabel independen yaitu Harga (X1), Lokasi (X2), dan Kualitas Produk (X3) terhadap variabel dependen yaitu Keputusan Pembelian (Y) dapat dihitung dengan mencari nilai koefisien determinasi. Dari hasil output SPSS didapatkan:

Tabel 4 Analisis Determinasi

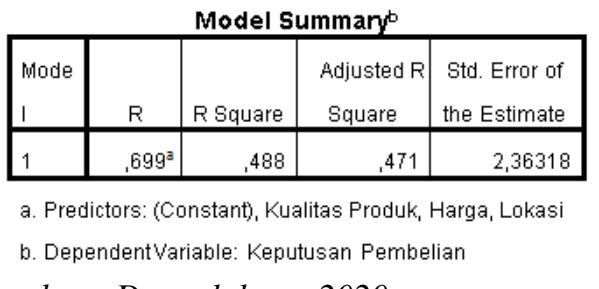

Sumber ; Data olahan ; 2020

Dari hasil tersebut didapatkan nilai koefisien determinasi (Adjusted R Square) sebesar 0,471 atau $47,1 \%$. Jadi dapat disimpulkan bahwa variabel Harga, Lokasi dan Kualitas Produk memberikan kontribusi terhadap perubahan-perubahan variabel Keputusan Pembelian Konsumen sebesar $47,1 \%$. sementara sisanya sebesar $52,9 \% .(100 \%-47,1 \%) \quad$ dipengaruhi oleh variabel-variabel lainnya yang tidak diteliti dalam penelitian ini.

\section{Uji t}

Uji_t digunakan untuk melihat pengaruh antara variabel bebas terhadap variabel terikat secara parsial, berikut adalah hasil out put SPSS untuk uji_t, sebagai berikut

\section{Tabel 5 Hasil Uji t}

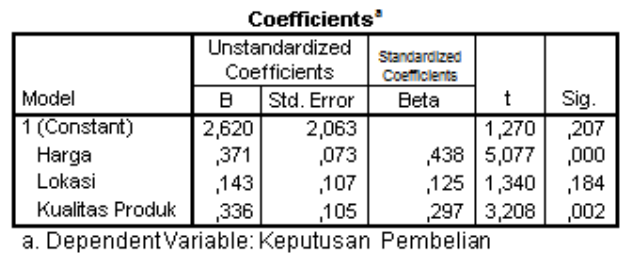

Sumber ; Data olahan ; 2020

Berdasarkan pada tabel 3 di atas diperoleh nilai t hitung untuk Harga (X1) sebesar (5,077), Lokasi (X2) sebesar (1,340), Kualitas Prosuk (X3) sebesar $(3,208)$. Sedangkan nilai kritis menurut tabel dengan tingkat signifikansi 5\% dengan menggunakan rumus t tabel $(\alpha / 2 ; \mathrm{n}$ $-\mathrm{k}) \mathrm{k}=6$ dan $\mathrm{n}=92$ adalah 1.98729 .

Hasil diatas diperoleh nilai t_hitung untuk masing-masing variabel adalah sebagai berikut : Untuk variabel Harga (X1) memiliki nilai t_hitung $(5,077)>$ dari nilai t_tabel (1,98729), sedangkan Lokasi (X2) memiliki nilai $\mathrm{t}$ _hitung $(1,340)>\mathrm{t}$ ttabel (1,98729). Kemudian Kualitas Produk (X3) memiliki nilai t_hitung $(3,208)>$ t_tabel $(1,98729)$. Hasil ini juga dapat disimpulkan bahwa secara parsial variabel Harga (X1) dan Kualitas Produk (X3) berpengaruh signifikan terhadap variabel keputusan pembelian konsumen CV. Zafira Teknik Pekanbaru. Sedangkan variabel Lokasi/X2 tidak berpengaruh signifikan terhadap variabel keputusan pembelian konsumen CV. Zafira Teknik Pekanbaru, hal tersebut dikarenakan nilai t_hitung $(1,340)<\mathrm{t}$ _tabel $(1,98729)$..

\section{Uji F}

Uji_F digunakan untuk melihat pengaruh antara variabel bebas (Harga, Lokasi dan Kualitas Produk) terhadap 
variabel terikat (Keputusan Pembelian) secara secara bersama-sama, berikut adalah hasil out put SPSS untuk uji_F:

\section{Tabel 6 Hasil Uji t}

\begin{tabular}{|c|c|c|c|c|}
\hline \multicolumn{5}{|c|}{ ANOVA $^{a}$} \\
\hline Model & $d f$ & Mean Square & $\bar{F}$ & Sig. \\
\hline 1 Regression & 3 & 158,065 & 28,304 & $.000^{\circ}$ \\
\hline Residual & 89 & 5,585 & & \\
\hline Total & 92 & & & \\
\hline
\end{tabular}

Sumber ; Data olahan ; 2020

Berdasarkan hasil SPSS diperoleh $F_{\text {hitung }}$ sebesar 28,304. Sedangkan $F_{\text {tabel }}$ diperoleh dengan (n-k)/(k-1): sebesar (92$4=88)(4-1=3 /$ kolom $)$, maka diperoleh nilai $\mathrm{F}$ tabel sebesar 2,71 $(\mathrm{a}=5 \%)$.

Maka disimpulkan bahwa $F_{\text {hitung }}$ sebesar 28,304 > $\mathrm{F}_{\text {tabel }}$ sebesar 2,71 sehingga secara bersama-sama/simultan variabel Harga (X1), Lokasi(X2) dan Kualitas Produk (X3) berpengaruh terhadap keputusan pembelian konsumen CV. Zafira Teknik Pekanbaru.

\section{PEMBAHASAN}

Hasil penelitian dari penelitian ini didapat bahwa:

Pengaruh Harga, Lokasi dan Kualitas Produk terhadap keputusan pembelian konsumen CV.Zafira Teknik Pekanbaru.

Berdasarkan hasil uji F, Maka disimpulkan bahwa $F_{\text {hitung }}$ sebesar 28,304 > $F_{\text {tabel }}$ sebesar 2,71 sehingga secara bersamasama/simultan variabel Harga (X1), Lokasi(X2) dan Kualitas Produk (X3) berpengaruh terhadap keputusan pembelian konsumen CV. Zafira Teknik Pekanbaru. Berarti Hipotesis pertama (H1) terbukti.

Ini menguatkan penelitian sebelumnya yang dilakukan oleh Susilo, Agung Joko (2017:6) bahwa Kualitas Produk, Harga dan Lokasi secara bersamasama berpengaruh dan signifikan terhadap keputusan pembelian konsumen. Penelitian lain yang dilakukan oleh Aulia (2017:59) bahwa kualitas produk, harga, dan lokasi mempunyai pengaruh yang signifikan secara simultan terhadap keputusan pembelian di Depot Pak Qomar Surabaya..

Eko dan Bisnis (Riau Economics and Business Reviewe) Volume 11, Nomor 1, 27 Maret 2020
Pengaruh Harga terhadap keputusan pembelian konsumen CV.Zafira Teknik Pekanbaru.

Variabel Harga memiliki 5 item pertanyaan. Dilihat dari tabel hasil uji konstanta dan koefisien regresi linear berganda diketahui bahwa setiap kenaikan 1 poin dari variabel harga (X1) mengakibatkan keputusan pembelian (Y) mengalami peningkatan sebesar 0,371 atau $37,1 \%$. Berdasarkan hasil uji hipotesis diduga variabel harga (X1) berpengaruh terhadap keputusan pembelian konsumen CV.Zafira Teknik Pekanbaru adalah terbukti berpengaruh positif dan signifikan. Dimana Harga (X1) memiliki nilai t_hitung (5.077) > dari nilai t_tabel $(1,98729)$ dan nilai signifikansi ( $\mathrm{P}$ Value) sebesar 0,000 yang berada dibawah 0,05 serta nilai koefisien regresi sebesar 0,371 .

Dalam penelitian ini Harga (X1) perlu diperhatikan oleh CV.Zafira Teknik Pekanbaru bahwa perlunya peningkatan strategi harga dalam usaha pintu besi ini. Harapannya adalah perusahaan ini dapat memenangkan persaingan dengan harga yang bersaing. Misal; membeli bahan baku langsung dari Medan atau Jakarta. Kemudian volume pembelian lebih banyak dari sekarang hingga bahan baku menjadi murah.. Karena menurut Utami (2008:9597), yang mengatakan bahwa harga merupakan jumlah dari seluruh nilai yang ditukar konsumen atas manfaat-manfaat memiliki atau menggunakan produk atau jasa tersebut.

\section{Pengaruh Lokasi terhadap keputusan pembelian konsumen CV.Zafira Teknik Pekanbaru.}

Variabel Lokasi (X2) ini juga memiliki 5 item pertanyaan. Dilihat dari tabel hasil uji konstanta dan koefisien regresi linear berganda diketahui bahwa setiap kenaikan 1 poin dari variabel lokasi (X2) mengakibatkan keputusan pembelian konsumen (Y) mengalami peningkatan sebesar 0,143 atau $14,3 \%$. Selanjutnya hipotesis diduga terdapat pengaruh signifikan lokasi secara parsial terhadap

P.ISSN: 1410-7988 E.ISSN: 2614-123X 
keputusan pembelian CV.Zafira Teknik Pekanbaru. Didapat hasil yaitu Lokasi (X2) memiliki nilai t_hitung (1.340) > t_tabel (1,98729), nilai signifikansi ( $\mathrm{P}$ Value) sebesar 0,184 yang berada diatas 0,05 serta nilai koefisien regresi sebesar 0,143. Dapat disimpulkan bahwa lokasi berpengaruh positif dan tapi tidak signifikan terhadap keputusan pembelian konsumen CV.Zafira Teknik Pekanbaru. .

Dalam penelitian ini lokasi CV.Zafira Teknik Pekanbaru mudah dijangkau namun kedatangan konsumen bukan dominan dipengaruhi oleh lokasi namun lebih pada harga dan kualitas hasil produk jadi pintu.

Hasil Penelitian ini berbeda dengan penelitian Aulia (2017) yang menyatakan bahwa lokasi mempengaruhikeputusan pembelian pada Depot Pak Qomar Surabaya.

\section{Pengaruh Kualitas Produk terhadap keputusan pembelian konsumen CV.Zafira Teknik Pekanbaru.}

Variabel Kualitas Produk (X3) ini juga memiliki 5 item pertanyaan. Dilihat dari tabel hasil uji konstanta dan koefisien regresi linear berganda diketahui bahwa setiap kenaikan 1 poin dari variabel kualitas produk (X3) mengakibatkan keputusan pembelian konsumen (Y) mengalami peningkatan sebesar 0,336 atau 33,6\%. Selanjutnya hipotesis diduga terdapat pengaruh signifikan kualitas produk secara parsial terhadap keputusan pembelian CV.Zafira Teknik Pekanbaru. Didapat hasil yaitu Kualitas Produk (X3) memiliki nilai t_hitung (3.208) $>$ t_tabel $(1,98729)$, nilai signifikansi $(\mathrm{P}$ Value) sebesar 0,002 yang berada dibawah 0,05 serta nilai koefisien regresi sebesar 0,336. Dapat disimpulkan bahwa kualitas produk berpengaruh positif dan signifikan terhadap keputusan pembelian konsumen CV.Zafira Teknik Pekanbaru. .

Dalam penelitian ini kualitas produk CV.Zafira Teknik Pekanbaru menggambarkan sejauh mana kemampuan produk tersebut dalam memenuhi kebutuhan konsumen. Hal ini menyatakan bahwa kualitas produk merupakan hal yang perlu mendapat perhatian utama dari perusahaan, karena kualitas produk berkaitan erat dengan pengambilan keputusan pembelian. Hasil Penelitian ini selaras dengan penelitian Aulia (2017) yang menyatakan bahwa kualitas produk mempengaruh ikeputusan pembelian pada Depot Pak Qomar Surabaya

\section{SIMPULAN}

Simpulan penelitian ini antara lain :

1. Berdasarkan hasil uji F, Maka disimpulkan bahwa Fhitung sebesar 28,304 > Ftabel sebesar 2,71 sehingga secara bersama-sama/simultan variabel Harga (X1), Lokasi(X2) dan Kualitas Produk (X3) berpengaruh terhadap keputusan pembelian konsumen $\mathrm{CV}$. Zafira Teknik Pekanbaru. Berarti Hipotesis pertama (H1) terbukti.

2. Berdasarkan hasil uji t untuk variabel Harga (X1) memiliki nilai t_hitung $(5,077)>$ dari nilai t_tabel $(1,98729)$, sedangkan Lokasi (X2) memiliki nilai t_hitung $(1,340)>$ t_tabel $(1,98729)$. Kemudian Kualitas Produk (X3) memiliki nilai t_hitung $(3,208)>$ t_tabel (1,98729). Hasil ini juga dapat disimpulkan bahwa secara parsial variabel Harga (X1) dan Kualitas Produk (X3) berpengaruh signifikan terhadap variabel keputusan pembelian konsumen CV. Zafira Teknik Pekanbaru. Sedangkan variabel Lokasi/X2 tidak berpengaruh signifikan terhadap variabel keputusan pembelian konsumen CV. Zafira Teknik Pekanbaru, hal tersebut dikarenakan nilai t_hitung $(1,340)<$ t_tabel $(1,98729)$.

Nilai koefisien determinasi (Adjusted R Square) sebesar 0,471 atau $47,1 \%$. disimpulkan bahwa variabel Harga, Lokasi dan Kualitas Produk memberikan kontribusi terhadap perubahan-perubahan variabel Keputusan Pembelian Konsumen sebesar $47,1 \%$. sementara sisanya sebesar 52,9\%.(100\%$47,1 \%)$ dipengaruhi oleh variabel- 
variabel lainnya yang tidak diteliti dalam penelitian ini.

\section{DAFTAR RUJUKAN}

Agus Purwoto. 2008. Panduan Laboratorium Statistik Inferensial. Jakarta: Grasindo.

Aulia, Siti. 2016. Pengaruh Kualitas Produk, Harga, dan Lokasi Terhadap Keputusan Pembelian (Studi Pada Depot Pak Qomar Surabaya). Jurnal Pendidikan Tata Niaga. Vol 3, No 3 (2016). Fakultas Ekonomi Universitas Negeri Surabaya

Assauri, Sofjan. 2009. Manajemen Pemasaran. Penerbit Raja Grafindo Persada, Jakarta

Ghanimata, Kamal. 2012. Analisis Pengaruh Harga, Kualitas Produk, dan Lokasi Terhadap Keputusan Pembelian (studi pada pembeli produk bandeng Jawana Elrina Semarang). Diponegoro Journal Of Management 1(2). http//eprints.undip.ac.id/36184/1/GHAN IMATA.pdf. Hal. 1-10.

Hermawan, Asep. 2013. Penelitian Bisnis. Universitas Trisakti, Jakarta

Husein, Umar, 2005, Riset Sumber Daya Manusia dalam organisasi, cetakan ketiga, PT Gramedia Pustaka Utama, Jakarta

Kotler \& Amstrong. 2009. Prinsip-prinsip pemasaran, Edisi Enam Belas, Jilid 1. Jakarta: Erlangga

N.C. Lempoy., S.L. Mandey., S.S.R. Loindong.2015. Pengaruh Harga, Lokasi, dan Fasilitas terhadap keputusan menggunakan jasa taman wisata Toar Lumimuut (Taman Eman) Sonder. Jurnal EMBA Vol.3 No.1 Maret 2015, Hal. 1072-1083. Fakultas Ekonomi Universitas Samratulangi.

Putro Shandy Widjoyo, Hatane Semuel, Ritzky Karina M.R. Brahmana. 2014. Pengaruh kualitas layanan dan kualitas produk terhadap kepuasan pelanggan dan loyalitas konsumen restoran Happy Garden Surabaya. Jurnal Manajemen Pemasaran Vol.2, No. 1, (2014) 1-9. Universitas Kristen Petra Surabaya
Sangadji dan Sopiah. 2013. Perilaku Konsumen. Penerbit Andi. Yogyakarta

Susilo, Agung Joko (2017). Pengaruh Kualitas Produk, Harga, dan Lokasi Terhadap Keputusan Pembelian Sepeda Motor Honda pada Agung Motor (Studi pada Konsumen Di Nganjuk Tahun 2015). SimkiEconomic Vol. 01 No. 06 Tahun 2017.Universitas Nusantara PGRI Kediri.

Sugiyono, 2012, Statistika Untuk Penelitian, CV Alfabeta, Bandung

Sugiyono. 2013. Metode Penelitian Manajemen.CV Alfabeta. Bandung.

Tjiptono, Fandy. 2010. Strategi Pemasaran. Edisi ke III.. Andi Offset Yogyakarta

2014. Manajemen Pemasaran Jasa. Andi Offset Yogyakarta

Utami, Christina Widya. 2008. Manajemen dagangan Dalam Bisnis Ritel. Malang: Bayumedia Publishing. 